\title{
I.I. Вініченко,
}

д.е.н., професор, завідувач кафедри економіки,

Аніпровсъкий державний аграрно-економічний університет

ORCID ID: 0000-0002-9527-1625

B. O. Lana, аспірант кафедри економіки, Аніпровсъкий державний аграрно-економічний університет ORCID ID: 0000-0002-5488-509X

\section{ОСОБАИВОСТІ ФОРМУВАННЯ ТА РОЗВИТКУ ІНТЕАЕКТУААЬНОГО КАПІТАЛУ АГРАРНИХ ПІАПРИЄМСТВ}

\author{
I. Vinichenko, \\ Doctor of Economic Sciences, Head of the Department of Economics, Dnipro State Agrarian and Economic University \\ V. Lapa, \\ postgraduate student at the Department of Economics, Dnipro State Agrarian and Economic University
}

PECULIARITIES OF FORMATION AND DEVELOPMENT OF INTELLECTUAL CAPITAL OF AGRARIAN ENTERPRISES

Статтю присвячено розгляду особливостей формування та розвитку інтелектуального капіталу аграрних підприємств. Зазначено, що побудова інноваційної системи аграрного сектору має грунтуватися на новітніх знаннях та впроваджуватися у бізнес-процеси сільськогосподарських підприємств. Визначено головні завдання перспективного розвитку украйнського агробізнесу в контексті розвитку інтелектуального капіталу. Проаналізовано скАад та структуру інтелектуального капіталу аграрних підприємств. Здійснено аналіз переваг та проблемних зон використання людського капіталу в аграрному секторі та розроблено напрямки їх розв'язання. За результатами аналізу структурного капіталу аграрних підприемств виявлено певні проблемні питання та запропоновано впроваджувати нову модель інноваційного операційного управління за рахунок техніко-технологічної стратегії, механізації, автоматизації, нових технологій виробництва, транспортування, зберігання та переробки агропродукції. Встановлено, що ефективне використання споживчого капіталу агропідприємСтв Аає можАивість зміцнити їх конкурентні позиції, отримати додаткові вигоди у господарській діядьності.

The article is devoted to the consideration of peculianities of formation and development of intellectual capital of agricultural enterprises. Statistics on the specific form of formalities and information on the agricultural sector. It is noted that it is an incentive and system sector of the economy to provide new knowledge and experience in the field of business processes from the point of view of the economy. Interact, promise to strengthen the Ukrainian agribusiness retail, innovative, social, cultural, innovative and scientific potential. The warehouse is analyzed and equipped with an international department. To interact, to ensure the competitiveness of the agricultural sector of the economy, aimed at improving the level of welfare of the population. Self-awareness of employees, investing in robotics in the professional competencies is the key to the development of agribusiness. Due to the structural analysis of the country, serious problems arose. problems arose with the transition to a new country, which included modern economic and economic problems, economic and economic costs. In this regard, every effort should be made to ensure that the agro-industrial complex takes measures to ensure competitiveness, as well as reviews for hospitalization in the state. It is noted that as regards the development of interethnic 
cooperation, multi-apartment farming may be required. All the necessary conditions to control the situation, structure, motivation and staff, as well as social and social problems in the country. The formulation and drawing of economic difficulties for the development of agro-industrial complexes, including scientific and economic mutual assistance, are not interconnected. Stressful relations in the sphere of economy and economy are given, as well as the possibility of obtaining a visa and services in the field of integrated mechanical mechanization and management in the country. The given directions of development of intellectual capital make it possible to define intellectual activity as a complex of basic management of intellectual economy of agrarian industrial complex and efficiency of practical use of capital.

Ключові слова: інтелектуальний капітал, людський капітал, структурний капітал, споживчий капітал, аграрні підприємства.

Key words: intellectual capital, buman capital, structural capital, consumer capital, agricultural enterprises.

\section{ПОСТАНОВКА ПРОБЛЕМИ}

Під час економічних та політичних перетворень, що здійснюються в Україні, головна увага має приділятися формуванню якісно нового кадрового потенціалу, за рахунок якого можливо вивести країну з глибокої економічної кризи. Основним джерелом конкурентних переваг сільськогосподарських підприємств стають елементи інтелектуального капіталу.

Актуальність теми дослідження обумовлена зростанням ролі інтелектуального капіталу у сучасній економіці аграрного сектору, що базується на управлінні знаннями. Тому пріоритетним завданням щодо формування та розвитку кадрового потенціалу агропідприємств стає пошук та використання інструментів підвищення творчого, інтелектуального капіталу людських ресурсів, спрямування їх на розвиток економіки агробізнесу, оптимізацію структури управління персоналом 3 врахуванням ментальних особливостей сільських територій.

Нових підходів потребує процедура оцінювання інтелектуального капіталу сільськогосподарських підприємств, а також доведення ефективності інвестицій у його елементи. Процес управління формуванням та розвитком інтелектуального капіталу агропідприємств потребує більш досконалих наукових рекомендацій, які побудовані на вивченні стійких тенденцій та закономірностей розвитку всього людського капіталу аграрної сфери економіки країни, а також його впливу на інтелект та рівень знань сільськогосподарського працівника. Саме тому особливої актуальності набуває проблема розробки напрямків щодо формування та розвитку інтелектуального капіталу на рівні сільськогосподарських підприємств, так і на рівні галузі загалом, що й розглядається у статті.

\section{АНАЛІЗ ОСТАННІХ ДОСЛІДЖЕНЬ}

Теоретичні та методологічні аспекти формування та розвитку інтелектуального капіталу обгрунтовуються у наукових працях багатої науковців як актуальне питання перспективного національного розвитку. Вагомий внесок у розв'язання теоретичних, методологічних та практичних проблем розвитку інтелектуального капіталу аграрного сектору здійснено такими вітчизняними та іноземними вченими: В. Андрійчук, Ю.Бажал, Г. Беккер, П. Гайдуцький, В. Аієсперов, М. Коденська, О. Мельник, А. Пригожин, П. Саблук, В. Ситник, А. Федулова, М. Фрідман, О. Шпикуляк, О. Шпичак, И. Шумпетер, В. Юрчишин та інших. Аослідження окремої проблематики щодо управління процесами формування та розвитку інтелектуального капіталу в аграрній сфері зустрічаються у публікаціях Г. Білова, А. Єрємєєвої, Г. Калетнік, А. Курило, У. Кьостер, Н. Сіренка, А. Смолій, Т. Шульца та інших.
Водночас більшість наукових досліджень не в повній мірі враховують кризові умови, в яких працюють сільськогосподарські працівники, а також специфічні особливості управління процесом формування, розвитку та оцінки інтелектуального капіталу аграрних підприємств. У зв'язку з чим виникає нагальна необхідність щодо проведення більш поглиблених досліджень у контексті вивчення інтелектуального капіталу аграрної сфери економіки країни.

\section{META CTATTI}

Метою статті є розробка напрямів вдосконалення управління формуванням та розвитком інтелектуального капіталу сільськогосподарських підприємств під час економічної кризи.

\section{ВИКЛАД ОСНОВНОГО МАТЕРІАЛУ ДОСЛІДЖЕННЯ}

Ефективний розвиток аграрного сектору економіки в значній мірі залежить від того, як успішно наукові знання генеруються та застосовуються у виробничоекономічній діяльності аграрних підприємств. Саме знання створюють підставу для впровадження інновацій та формування кваліфікованих трудових ресурсів, стають джерелом інноваційного розвитку та конкурентоспроможності агропідприємств та галузі в цілому. Аграрна наука $є$ частиною комплексної системи, що здатна перетворювати знання у нові технології, якісну сільськогосподарську продукцію та послуги, які мають свого споживача.

Ряд вчених згодні з тим, що побудова інноваційної системи аграрного сектору має грунтуватися на новітніх знаннях та впроваджуватися у бізнес-процеси сільськогосподарських підприємств [2-5].

Так, Коломієць Т.В. зазначає, що одним із основних найперспективніших напрямів розвитку українського агробізнесу є інноваційний, який грунтується на ефективному використанні людського, інтелектуального, освітнього та наукового потенціалів. Водночас перехід на даний вектор розвитку передбачає трансформацію системи "освіта — наука - виробництво" та побудову інноваційних систем як на регіональному рівні, так і національному. Ефективне використання такої системи дає змогу створювати інноваційний продукт із високою доданою вартістю, капіталізувати інтелектуальні ресурси, створюючи таким чином інтелектуальний капітал суб'єктів господарювання і держави в цілому [3].

Використання концепції інноваційного розвитку 3 метою підвищення ефективності агробізнесу залежить не тільки від впливу науки, але й від впливу змін, що відбуваються у зовнішньому середовищі. У зв'язку з чим, можливо відокремити шість видів змін: 
1) спрямовування науки на запити агропідприємців та перебудова наукових досліджень в бік вимог споживачів, що змінюються;

2) з метою збереження конкурентоспроможності та виживання у сучасних умовах аграрним підприємствам необхідно постійно впроваджувати новації;

3) зростання кількості приватних форм господарювання, які зацікавлені у нових знаннях, інформації та новітніх технологіях;

4) зростання попиту на інформаційні та телекомунікаційні технології в агросекторі, що дає змогу запозичувати знання, отримані в інших сферах або для інших цілей;

5) структура знань в аграрному секторі змінюється - спостерігається значне зростання освітянського та професійного рівня сільськогосподарських фахівців у порівнянні з рівнем запропонованих науково-дослідних розробок. Науковці через нестачу фінансового забезпечення не встигають швидко та адекватно відповідати на запити аграріїв. За ефективної взаємодії науковців та практиків агробізнесу можуть генеруватися нові ідеї та продуктивні рішення щодо технічних, економічних та організаційно-управлінських проблем наявного та перспективного характеру;

6) чинник глобалізації все більше визначає розвиток аграрного сектору у перспективі. Капітал, ринок, праця, інформація та технології, стандарти можуть бути організованими в будь-якій країні світу та здійснювати позитивний вплив на розвиток вітчизняних аграрних підприємств.

Отже, Аля того щоб перетворити наявний науковотехнічний потенціал аграрного сектору у дієвий чинник його соціально-економічного розвитку, необхідно перейти до політики комплексної підтримки інноваційних процесів за рахунок формування та розвитку інтелектуального капіталу. Найбільш важливою проблемою $є$ створення сприятливих фінансово-економічних та правових умов 3 метою формування вітчизняної інноваційної та інтелектуальної системи аграрного сектору в умовах кризи. Під час економічних негараздів, що охопили країну, агробізнес стає пріоритетним напрямом розвитку української економіки, бо майже половину їі території складають надзвичайно родючі грунти. Водночас, щоб конкурувати на світовому ринку, фактору родючості земельних ресурсів недостатньо. Зокрема відомо, що українські аграрії в середньому збирають у 2 рази менше озимої пшениці з 1 гектару, ніж їх колеги у Франції та Німеччині. Крім того, сільськогосподарська продукція аграрних підприємств у всьому світі майже однакова - зерно озимої пшениці, кукурудзи, соняшнику, м'ясо птиці чи свинина.

Отже, з метою підвищення конкурентоздатності вітчизняних сільськогосподарських підприємств на світовому ринку пріоритетним завданням в агробізнесі має стати підвищення операційної ефективності, освоєння нових технологій з вирощування агропродукції, а також раціональне використання фінансових інструментів для досягнення високих виробничо-економічних показників. Саме ефективне управління інтелектуальним капіталом дозволить українським аграріям бути успішними в довгостроковій перспективі.

Все більше уваги приділяється актуальним питанням управління бізнес-процесами сільськогосподарських підприємств, економіці агробізнесу, побудові вертикально-інтегрованих структур, викликам міжнародних ринків тощо. Визначальними для досягнення операційної ефективності українських аграрних компаній стають професії агронома, технолога з виробництва чи переробки сільськогосподарської продукції, біотехнолога та лікаря ветеринарної медицини. На сучасному етапі фінансово-економічного стану агробізнесу не менш важливими залишаються питання навчання фахівців 3 управління фінансовими потоками, залучення довгострокового недорогого фінансування, 3 управління діловою репутацією агропідприємств, спеціалістів з комунікацій, маркетингу та логістики.

Головна увага має приділятися підготовці вузькопрофільних спеціалістів, які володіють цифровими технологіями та можуть їх ефективно впровадити до виробничої діяльності аграрних підприємств. 3 розвитком інформаційних технологій інновації у всіх сферах, зокрема й аграрній, набувають обертів. Тому відповідні фахівці, що володіють сучасними знаннями та пройшли стажування в передових вітчизняних агрокомпаніях, в провідних аграрних країнах, Франція, Ізраїль, Нідерланди, Аанія, будуть користуватися значним попитом.

Таким чином, головними завданнями перспективного розвитку українського агробізнесу в контексті розвитку інтелектуального капіталу є:

1) уточнення сутності та особливостей інтелектуального капіталу сільськогосподарських підприємств;

2) обгрунтування напрямків формування та розвитку окремих складових інтелектуального капіталу (людського, організаційного, споживчого), а також управління їх взаємодією;

3) уточнення наявних та з'ясування нових методів оцінки інтелектуального капіталу агропідприємств, а також ефективності інвестицій до нього;

4) розробка технологій управління інтелектуальним капіталом агросфери.

Останнім часом спостерігається стрімкий розвиток наукоємних технологій в аграрному секторі, зокрема, біотехнологія, генна інженерія, комп'ютерне програмування, точне землеробство, цифрові агротехнології тощо. Саме інтелектуальна економіка стимулює отримання високих прибутків, тобто саме інтелектуальний капітал виступає гарантом зростання конкурентоспроможності аграрних підприємств.

Зазначимо, що більшість дослідників та практиків дійшла висновку, що на рівні підприємства інтелектуальний капітал є сумою трьох складових, які представлені на рисунку 1.

\юдський капітал аграрних підприємств має деякі особливості: сезонність використання, слабкий розвиток соціальної інфраструктури села, важкі умови праці, низький рівень оплати праці, недостатня професійна підготовка персоналу, відтік молодих і кваліфікованих кадрів до міст, інших країн тощо. Зокрема, як зазначають вчені, сільськогосподарський працівник зазвичай розцінюється не як носій людського капіталу і джерело унікальних компетенцій, конкурентних переваг, а як один із факторів виробництва, обсяг якого збільшується пропорційно до зміни площ сільськогосподарських угідь і залученої техніки [1].

На підставі аналізу сильних та слабких позицій людського капіталу в аграрних підприємствах розглянемо напрями вирішення його найбільш проблемних зон (табл. 1).

Найбільшими проблемними зонами, що призводять до плинності сільськогосподарських працівників, було виявлено неефективний мотиваційний менеджмент аграрних підприємств, відсутність вузькоспеціалізованих знань та професійних навичок щодо практичного застосування агротехнологій, незадовільна соціальна інфраструктура села. Ао переваг людського капіталу віднесено бажання працівників здобувати спеціальні знання та оволодівати практичними навичками 3 агровиробництва за умови створення ефективної системи мотивації та стимулювання праці. Також встановлено, що більшість сільськогосподарських підприємств має достатній ресурсний потенціал щодо впровадження новітніх технологій. Отже, до шляхів розв'язання слабких позицій людського капіталу та з урахування їх сильних боків пропонується вдосконалити мотиваційне управління в сільськогосподарських підприємствах, покращити соціально-побутові умови проживання, створювати систему неперервного навчання у сфері сільського господарства, починаючи з випускників шкіл, 


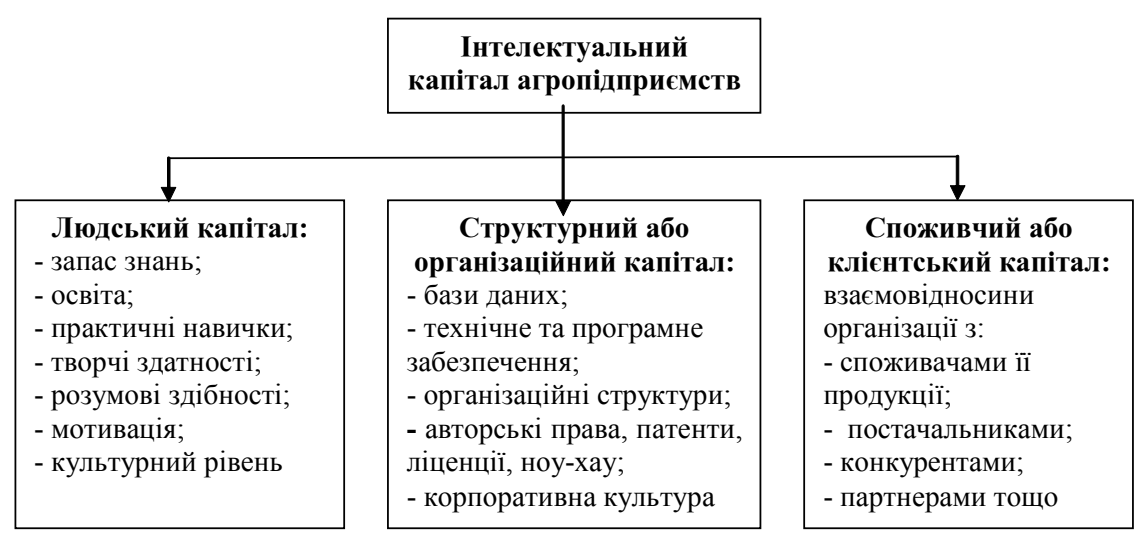

Рис. 1. Складові та структура інтелектуального капіталу агропідприємств

Ажерело: розроблено авторами.

впроваджувати науково-технічні та дослідно-конструкторські розробки у технологічний розвиток агровиробництва.

Таким чином, підвищення конкурентоспроможності аграрного сектора економіки країни залежить від рівня розвитку людського капіталу. Саме освіченість працівників, інвестування роботодавцем у підвищення їх професійних компетенцій є запорукою зростання прибутковості агробізнесу [6].

Тому агротоваровиробникам варто акцентувати увагу на взаємодії аграрної освіти, науки та дорадчих послуг, впроваджувати інновації і, за рахунок людського капіталу, забезпечувати конкурентні переваги на ринкy.

Структурний або організаційний капітал є сукупність ресурсів підприємства у вигляді ноу-хау чи інших об'єктів інтелектуальної власності, інформаційних продуктів, програмного забезпечення, технологій, систем менеджменту та економічної безпеки, а також організаційної культури, які дозволяють здійснювати управління інтелектуальним капіталом підприємства для підвищення ефективності його діяльності [4].

Під час здійснення операційного менеджменту та управління виробничим потенціалом все більше підприємств аграрного сектору використовують програмні засоби та забезпечення, формують бази даних, будують раціональну організаційну структуру, отримують патенти за винаходи, розробляють товарні знаки, а також використовують інші організаційні механізми, які забезпечують підвищення виробничої продуктивності сільськогосподарських працівників та загалом, гарантують успішне функціонування агропідприємств. Розглянемо сильні та слабкі позиції структурного капіталу аграрних підприємств, а також запропоновані шляхи вирішення його проблемних зон (табл. 2).

За результатами аналізу структурного капіталу аграрних підприємств було виявлено певні проблемні зони такі, як не ефективне операційне управління агропідприємствами через низький рівень володіння новітніми агротехнологіями, зокрема, цифровими, зниження якісних параметрів сільськогосподарської продукції та зменшення виробництва їх певних видів через вимушену економію внаслідок негативного впливу кризових явищ, скорочення терміну експлуатації сільськогосподарської техніки; необгрунтоване зростання цін на матеріально-технічні ресурси, нераціональна організаційна структура, а також не достатнє використання ноухау, винаходів, небажання оформляти патенти тощо.

3 метою покращання використання структурного капіталу для перспективного розвитку агропідприємств пропонується впроваджувати нову модель інноваційного операційного управління за рахунок техніко-техно-

Таблиця 1. Напрями вирішення проблемних зон людського капіталу

\begin{tabular}{|c|c|c|c|}
\hline 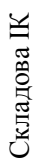 & $\begin{array}{c}\text { Сильні боки людського } \\
\text { капіталу }\end{array}$ & $\begin{array}{c}\text { Проблемні зони людського } \\
\text { капіталу }\end{array}$ & Шляхи вирішення проблем \\
\hline 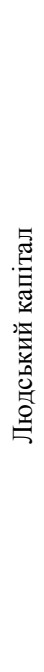 & $\begin{array}{l}\text { 1) наявність освічених та } \\
\text { високопрофесійних } \\
\text { фахівців аграрного } \\
\text { профілю; } \\
\text { 2) бажання здобувати } \\
\text { спеціальні знання шляхом } \\
\text { проходження навчання у } \\
\text { закладах вищої освіти та } \\
\text { агробізнес-школах; } \\
\text { 3) мотивація працівників } \\
\text { щодо оволодіння } \\
\text { практичних навичок з } \\
\text { агровиробництва; } \\
\text { 4) наявність ресурсного } \\
\text { потенціалу щодо } \\
\text { впровадження новітніх } \\
\text { техніко-технологічних } \\
\text { розробок до роботи } \\
\text { агропідприємств }\end{array}$ & $\begin{array}{l}\text { 1) відсутність дієвої мотивації } \\
\text { праці с/г працівників, зокрема у } \\
\text { винахідників та } \\
\text { раціоналізаторів; } \\
\text { 2) зниження кадрового } \\
\text { потенціалу, «кадровий голод», } \\
\text { проблема підготовки } \\
\text { висококваліфікованих кадрів } \\
\text { аграрного профілю; } \\
\text { 3) відсутність у працівників } \\
\text { професійних навичок щодо } \\
\text { застосування нових } \\
\text { агротехнологій; } \\
\text { 4) відсутність нормальних } \\
\text { соціально-побутових умов } \\
\text { проживання на селі; } \\
\text { 5) низький рівень заробітної } \\
\text { плати, що негативно } \\
\text { позначається на бажанні } \\
\text { випускників зво працювати в } \\
\text { агропідприємствах }\end{array}$ & $\begin{array}{l}\text { 1) підвищення рівня оплати } \\
\text { праці с/г працівникам та } \\
\text { обов'язкове оформлення права } \\
\text { на інтелектуальну власність } 3 \\
\text { можливістю одержання в } \\
\text { подальшому роялті; } \\
\text { 2) створення системи } \\
\text { неперервного навчання у сфері } \\
\text { сільського господарства } \\
\text { починаючи з випускників шкіл; } \\
\text { 3) вдосконалення комплексу } \\
\text { технологічних, економічних та } \\
\text { вузькоспеціалізованих прийомів } \\
\text { в агрономії, біотехнології, } \\
\text { ветеринарній медицині тощо; } \\
\text { 4) покращення соціальної } \\
\text { інфраструктури на селі за } \\
\text { рахунок впровадження } \\
\text { державних програм розвитку } \\
\text { сільських територій }\end{array}$ \\
\hline
\end{tabular}


Таблиця 2. Напрями вирішення проблемних зон структурного капіталу підприємств аграрного сектору

\begin{tabular}{|c|c|c|c|}
\hline 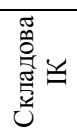 & $\begin{array}{c}\text { Сильні боки } \\
\text { структурного капіталу }\end{array}$ & $\begin{array}{c}\text { Проблемні зони } \\
\text { структурного капіталу }\end{array}$ & Шляхи вирішення проблем \\
\hline 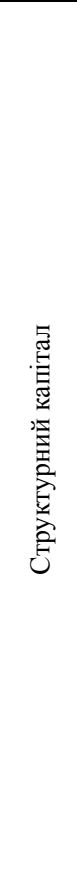 & $\begin{array}{l}\text { 1) наявність значної } \\
\text { кількості } \\
\text { агропідприємств, які } \\
\text { здатні впроваджувати } \\
\text { нові технології; } \\
\text { 2) керівники та } \\
\text { спеціалісти } \\
\text { агропідприємств } \\
\text { зацікавлені у набутті } \\
\text { нових спеціалізованих } \\
\text { аграрних знань; } \\
\text { 3) наявність } \\
\text { практичного досвіду в } \\
\text { освоєнні агробізнесу в } \\
\text { конкурентних умовах; } \\
\text { 4) цільове } \\
\text { виробництво } \\
\text { сільськогосподарської } \\
\text { продукції у } \\
\text { відповідності до } \\
\text { ринкових умов; } \\
\text { 5) наявність ресурсів } \\
\text { для впровадження } \\
\text { інновацій }\end{array}$ & $\begin{array}{l}\text { 1) не ефективне } \\
\text { операційне управління } \\
\text { агропідприємствами; } \\
\text { 2) виробництво } \\
\text { сільськогосподарської } \\
\text { продукції низької якості; } \\
\text { 3) скорочення виробництва } \\
\text { певних видів } \\
\text { сільськогосподарських } \\
\text { культур та порід тварин; } \\
\text { 4) скорочення терміну } \\
\text { експлуатації } \\
\text { сільськогосподарської } \\
\text { техніки; } \\
\text { 5) необгрунтоване } \\
\text { зростання цін на } \\
\text { матеріально-технічні } \\
\text { ресурси; } \\
\text { 6) нераціональна } \\
\text { організаційна структура; } \\
\text { 7) не достатня кількість } \\
\text { ноу-хау, винаходів, } \\
\text { патентів }\end{array}$ & $\begin{array}{l}\text { 1) впровадження нової моделі } \\
\text { інноваційного операційного } \\
\text { управління за рахунок техніко- } \\
\text { технологічної стратегії, механізації, } \\
\text { автоматизації, нових технологій } \\
\text { виробництва, транспортування, } \\
\text { зберігання та переробки } \\
\text { агропродукції; } \\
\text { 2) виробнича інтеграція або } \\
\text { об’єднання зусиль агропідприємств } \\
\text { різних організаційно-правових форм } \\
\text { господарювання; } \\
\text { 3) перебудова агропідприємств на } \\
\text { сучасну інформаційну та } \\
\text { технологічну основу; } \\
\text { 4) впровадження критеріїв оцінки ІК } \\
\text { (задоволеність споживачів, повнота } \\
\text { використання інформаційних } \\
\text { технологій, розвиток людського } \\
\text { капіталу); } \\
\text { 5) впровадження обліково- } \\
\text { аналітичного кластеру управління } \\
\text { витратами та якістю продукції; } \\
\text { 6) надання державної підтримки } \\
\text { щодо кредитування, страхування } \\
\text { 7) впровадження державних програм } \\
\text { щодо діджиталізації виробничого } \\
\text { розвитку агропідприємств }\end{array}$ \\
\hline
\end{tabular}

Ажерело: складено авторами.

логічної стратегії, механізації, автоматизації, нових технологій виробництва, транспортування, зберігання та переробки агропродукції. Також особливої уваги набувають об'єкти науково-технічної інформації (науковотехнічна документація, наукові відкриття, раціоналізаторські пропозиції, селекційні досягнення щодо розробки нових сортів та гібридів сільськогосподарських культур та порід тварин; об'єкти промислової власності (винаходи; корисні моделі; промислові зразки; захист від недобросовісної конкуренції: захист через адміністративні чи судові органи - неправомірне використання ділової репутації агропідприємця, створення перешкод в процесі конкуренції, неправомірне використання комерційної таємниці); системи організації виробництва, маркетингу, управління якістю продукції, кадрами, фінансами, політикою капіталовкладень; виробничо-комерційний досвід організації виробництва, маркетингу і навчання персоналу. Аоцільно проводити виробничу інтеграцію або об'єднувати зусилля підприємств різних організаційно-правових форм господарювання щодо залучення техніко-технологічних новацій. Необхідно звернути увагу на докорінну перебудову агропідприємств в бік сучасної інформаційної та технологічної трансформації, створювати обліково-аналітичні кластери управління витратами та якістю продукції, розробляти та впроваджувати критерії оцінки інтелектуального капіталу. Окремого значення набуває надання державної підтримки щодо пільгового кредитування та страхування агробізнесу, а також впровадження державних програм щодо діджиталізації виробничого розвитку сільськогосподарських підприємств.

Таким чином, структурний капітал підприємства забезпечує узагальнення, формалізацію та документування знань і досвіду, що можуть бути використані для інноваційного розвитку підприємства. Позитивна організаційна культура формує сприятливе середовище для ініціативності й творчої активності працівників, підвищує їх зацікавленість, відкриває можливості щодо підвищення ефективності діяльності підприємства. Використання структурного капіталу забезпечує перетворен- ня результатів творчої праці на матеріальні продукти, а потім їх комерціалізацію.

Споживчий або клієнтський капітал є капіталом, до якого прийнято відносити товарні знаки і знаки обслуговування, фірмові найменування, ділову репутацію, присутність "своїх людей" в організаціях-партнерах або організаціях-клієнтах, наявність постійних споживачів, повторні контракти зі споживачами тощо [5].

Ао елементів споживчого капіталу відноситься:

1) ділова репутація, яка формується за рахунок позитивного іміджу аграрного підприємства, його фінансового стану, репутації керівника та соціальної відповідальності підприємства;

2) система відносин зі споживачами, яка складається із стабільності клієнтської бази, наявності інформації про клієнтів та історії відносин з ними, задоволеності потреб клієнтів, довіри клієнтів до підприємства;

3) бренди (товарні марки), до їх чинників відносять відображення високої якості товару; оригінальний дизайн товарної марки; використання інструментів нейромаркетингу; максимальна відмінність від брендів-конкурентів;

4) система відносин $з$ постачальниками та іншими контрагентами, яка передбачає наявність постійних контрагентів-партнерів, бази даних (інформації, історії відносин) про співпрацю; мотивацію контрагентів до співпраці; орієнтація на стратегічне партнерство.

Враховуючи виявлені сильні сторони споживчого капіталу підприємств аграрного сектору та зазначені проблемні зони пропонуємо певні напрямки покращення якості споживчого капіталу в агробізнесі (табл. 3).

Таким чином, зазначимо, що з огляду на структуру споживчого капіталу та можливість грошової оцінки його складових він становить значну частку грошового еквіваленту вартості інтелектуального капіталу загалом. Ефективне використання споживчого капіталу агропідприємств дає можливість зміцнити конкурентні позиції, отримати додаткові вигоди у їх господарській діяльності.

Отже, формування та розвиток інтелектуального капіталу аграрних підприємств залежить від здійснен- 
Таблиця 3. Напрями вирішення проблемних зон споживчого капіталу підприємств аграрного сектору

\begin{tabular}{|c|c|c|c|}
\hline 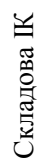 & $\begin{array}{c}\text { Сильні боки } \\
\text { споживчого капіталу }\end{array}$ & $\begin{array}{c}\text { Проблемні зони споживчого } \\
\text { капіталу }\end{array}$ & Шляхи вирішення проблем \\
\hline 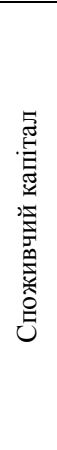 & $\begin{array}{l}\text { 1) наявність ринків } \\
\text { 3буту аропродукції; } \\
\text { 2) наявність ресурсної } \\
\text { бази для розвитку } \\
\text { партнерських відносин; } \\
\text { 3) попит на } \\
\text { сільськогосподарську } \\
\text { продукцію; } \\
\text { 4) сформована ділова } \\
\text { репутація } \\
\text { агропідприємств }\end{array}$ & $\begin{array}{l}\text { 1) відсутність програм } \\
\text { антикризового управління } \\
\text { агропідприємствами; } \\
\text { 2) недостатній розвиток } \\
\text { маркетингу в діяльності } \\
\text { агропідприємств; } \\
\text { 3) недостатній розвиток } \\
\text { конкуренції; } \\
\text { 4) залежність агровиробників } \\
\text { від монополізованих ринків } \\
\text { збуту; } \\
\text { 5) бюрократичні проблеми } \\
\text { під час оформлення товарних } \\
\text { марок }\end{array}$ & $\begin{array}{l}\text { 1) розробка та впровадження } \\
\text { інноваційно-інвестиційної } \\
\text { стратегії агробізнесу; } \\
\text { 2) розробка та впровадження } \\
\text { антикризових програм щодо } \\
\text { підтримки агропідприємств; } \\
\text { 3) впровадження нових } \\
\text { аграрних науково-дослідних } \\
\text { технологій та } \\
\text { конструкторських розробок } \\
\text { 4) надання кваліфікованих } \\
\text { маркетингових знань } \\
\text { спеціалістам агропідприємств }\end{array}$ \\
\hline
\end{tabular}

Ажерело: складено авторами.

ня науково-дослідної та виробничої діяльності щодо наукового забезпечення розвитку сільського господарства країни.

\section{ВИСНОВКИ}

Отже, на підставі проведеного аналізу проблемних зон інтелектуального капіталу підприємств аграрного сектору та виявлення шляхів їх розв'язку зроблено висновок про доцільність розробки та впровадження стратегії інноваційного розвитку економіки, що спирається на інтелектуальний капітал сільськогосподарських працівників та створює умови для найбільш ефективного застосування знань й умінь трудових ресурсів щодо техніко-технологічного вдосконалення операційної та виробничо-економічної діяльності агропідприємств. Розв'язання проблем інтелектуального капіталу сільськогосподарських підприємств знаходиться в площині системи управління знаннями та капіталом. Наведені напрями розвитку інтелектуального капіталу дають можливість використовувати найбільш ефективним чином інтелектуальну діяльність трудових ресурсів аграрного сектору.

Подальші дослідження будуть пов'язані з проблемами відтворення людського капіталу в сільськогосподарських підприємствах на підставі виявлення територіально-демографічних характеристик з урахуванням диверсифікації праці та в умовах ризикованого аграрного виробництва.

\section{Мітература:}

1. Запухляк B.М. Аюдський капітал як чинник підвищення конкурентоспроможності аграрного сектору економіки України / B.M. Запухляк, O.I. Мельник // Агросвіт. - 2017. - № 3. - С. 40-44.

2. Каленюк I.C. Інтелектуальний капітал: проблеми визначення та структуризації/ I.C. Каленюк // Науковий вісник ЧАІЕУ. - 2008. - № 1. - С. 4-13.

3. Коломієць Т.В. Формування аграрної інноваційної системи як шлях до накопичення інтелектуального капіталу підприємств агросектору / Т.В. Коломієць // Економіка АПК. - 2016. - № 11. - С. 94-99.

4. Кравчук Н.О. Роль структурного капіталу підприємства у складі його інтелектуального капіталу/Н.О. Кравчук // Науковий вісник Херсонського державного університету. - 2014. - Вип. 6. - Ч. 2. - С. 216-218.

5. Курило $\Lambda$.І. Формування інтелектуального капіталу в аграрній сфері: теоретичний аспект / $\Lambda$.I. Курило // Економіка АПК. - 2014. - № 8. - С. 5-12.

6. Шпак Н. Особливості формування людського капіталу в аграрному секторі інформаційної економіки / Н. Шпак / Проблеми і перспективи економіки та управління. - № 3 (11). - 2017. - С. 28-38.

\section{References:}

1. Zapukhlyak, V.M. (2017), "Human capital is a factor in the competitiveness of competition with the agrarian sector of the Ukrainian economy", Agrosvit, vol. 3, pp. 4044.

2. Kalenyuk, I.S. (2008), "Intellectual capital - problems of definition and structuring", Naukovyu Visnyk ChDIEU, vol. 1 , pp. $4-13$.

3. Kolomiets, T.V. (2016), "Formation of agrarian innovation system as a way to accumulate the intellectual capital of the agricultural sector enterprises", Economika APK. vol. 11, pp. 947-99.

4. Kravchuk, N. O. (2014), "The role of the structural capital of the enterprise in the composition of its intellectual capital", Naukovyu Visnyk Khersonskoho natsional'noho universytetu,vol. 6, pp. 216-218.

5. Kyrulo, L. I. (2014), "Formation of intellectual capital in agrarian sphere - theoretical aspect", Economika APK, vol. 8 , pp. $5-12$.

6. Shpak, N. (2017), "Features of formation of human capital in agrarian sector of information economy", Problemy ta perspektyvy ekonomiky ta upravlinnya, vol. 3 , pp. $28-38$.

Стаття надійшла до редакиї 07.04.2020 p.

\section{wWw. dy.nayka.com.ua}

Електронне фахове видання

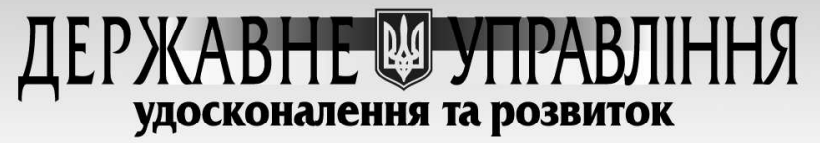

Виходить 12 разів на рік

включено до переліку наукових фахових видань України 3 Питань ДЕРЖАВНОГО УПРАВЛІННЯ

(Категорія «Б»)

Наказ Міністерства освіти і науки України від 28.12.2019 №1643

e-mail: economy_2008@ukr.net тел.: (044) 223-26-28 (044) 458-10-73 